\title{
Membrane stability and antioxidant enzyme activity of rice seedlings in response to short-term high temperature treatments
}

\author{
Anoma Dongsansuk $^{1 *}$, Warunya Paethaisong ${ }^{2}$, and Piyada Theerakulpisut ${ }^{2}$ \\ ${ }^{1}$ Khon Kaen University, Faculty of Agriculture, Mittraphap Road Muang, 40002, Khon Kaen, Thailand. \\ "Corresponding author (danoma@kku.ac.th). \\ ${ }^{2}$ Khon Kaen University, Faculty of Science, Mittraphap Road Muang, 40002, Khon Kaen, Thailand.
}

Received: 9 May 2021; Accepted: 12 August 2021; doi:10.4067/S0718-58392021000400607

\begin{abstract}
The impact of temperature on plants varies depending on the temperature level and the time of exposure. The aim of this study was evaluating different short-term temperatures to stimulate rice (Oryza sativa L.) seedling growth indicated by some physiological functions. Thus, oxidative stress, membrane stability and antioxidant activity in 'Dular', 'IR64' and 'KDML105' rice seedlings were evaluated in response to 25,35 and $45^{\circ} \mathrm{C}$ for $30 \mathrm{~min}$. At $25^{\circ} \mathrm{C}$, 'IR64' showed higher electrolyte leakage (EL) percentages, protein contents and peroxidase (POX) activity but lower hydrogen peroxide $\left(\mathrm{H}_{2} \mathrm{O}_{2}\right)$ content. At $35^{\circ} \mathrm{C}$, the highest $\mathrm{H}_{2} \mathrm{O}_{2}$ content was found in 'KDML105' followed by 'IR64' and 'Dular'. In all rice seedlings the lowest EL was after $35^{\circ} \mathrm{C}$ exposure and activities of catalase (CAT) in 'IR64' and 'KDML105', ascorbate peroxidase (APX) in 'Dular', 'IR64' and 'KDML105' and glutathione reductase (GR) in 'Dular', 'IR64' and 'KDML105', and superoxide dismutase (SOD) in 'Dular' and 'KDML105' were stimulated by higher $\mathrm{H}_{2} \mathrm{O}_{2}$ production. At $45^{\circ} \mathrm{C}$, all rice seedlings showed pronounced EL increase but reduced $\mathrm{H}_{2} \mathrm{O}_{2}$ production, protein content and all antioxidant enzyme activities. These results suggested that short-term temperature at $35^{\circ} \mathrm{C}$ was an optimum condition for all rice seedlings as indicated by the least membrane damage $(\mathrm{EL} \approx 45.04 \%)$ and induction of most antioxidant enzymes (CAT, APX, GR and $\mathrm{SOD} \approx 48.29 \mathrm{nmol} \mathrm{min}^{-1} \mu \mathrm{g}^{-1}$ protein, $247.49 \mathrm{ng}$ ascorbic acid $\min ^{-1} \mu \mathrm{g}^{-1}$ protein, $0.16 \mu \mathrm{M} \mathrm{min}^{-1} \mu \mathrm{g}^{-1}$ protein and 0.078 unit $\mathrm{min}^{-1} \mu \mathrm{g}^{-1}$ protein, respectively). This temperature induced higher $\mathrm{H}_{2} \mathrm{O}_{2}$ production which plays a significant role in signaling molecules to stimulate protein function and antioxidant enzyme activities. While short-term $45^{\circ} \mathrm{C}$ proved to be damaging temperature for all rice seedlings because of membrane damage and decreased reactive oxygen species defense mechanism.
\end{abstract}

Key words: Antioxidant enzyme, electrolyte leakage, heat stress, hydrogen peroxide, Oryza sativa.

\section{INTRODUCTION}

Temperature is one of the most important environmental factors affecting plant growth and yield production. At the present, global warming is a serious threat to agricultural productivity. High temperature adversely affects plant growth and development, limits plant biomass production and reduces yield quality in tropical and subtropical areas (Hasanuzzaman et al., 2013b). In addition, it causes an alteration of the physiological processes, biochemistry, and gene regulation (Bita and Gerats, 2013). Temperature changes may also induce cellular responses by perceiving and signaling transduction into cells (Hemantaranjan et al., 2014). Under high temperature, plants demonstrate various survival mechanisms such as avoidance, acclimation or tolerance through molecular, biochemical and physiological processes.

Rice (Oryza sativa L.) is the main food crop and plays a vital role in food security in many countries including Thailand. The optimum temperature of rice growth was reported at approximately $33{ }^{\circ} \mathrm{C}$, and temperatures over $33{ }^{\circ} \mathrm{C}$ could impose negative effects on rice yield (Sukkeo et al., 2017). Plants exposed to temperature above $5{ }^{\circ} \mathrm{C}$ of optimum growth 
temperature responded at the cellular level with the production and accumulation of reactive oxygen species (ROS) such as superoxide radicals $\left(\mathrm{O}_{2}{ }^{*}\right)$, hydrogen peroxide $\left(\mathrm{H}_{2} \mathrm{O}_{2}\right)$ and hydroxyl radicals $\left(\mathrm{OH}^{*}\right)$. When plants are exposed to stress, ROS plays an important role in signal transduction. High temperature leads to an increase in membrane fluidity (Asthir, 2015) and oxidative stress (Hasanuzzaman et al., 2013a) resulting in cell membrane damage and electrolyte leakage by lipid peroxidation. Ali et al. (2013) reported that an increased in $\mathrm{H}_{2} \mathrm{O}_{2}$ in rice was found after the plants were treated with high temperature at $42 \pm 3{ }^{\circ} \mathrm{C}$ for 24 and $48 \mathrm{~h}$. When ROS burst occurs under high temperature, plants respond by increasing the production and activity of antioxidant enzymes. The antioxidant enzymes such as peroxidase (POX), catalase (CAT), ascorbate peroxidase (APX), superoxide dismutase (SOD) and glutathione reductase (GR) protect cell damage due to ROS in plant cells and subcellular system (Hasanuzzaman et al., 2013b). Timabud and Pongdontri (2015) reported that after $8 \mathrm{~h}$ at $40^{\circ} \mathrm{C}$, POX activity in rice 'IR64' was higher than that of 'N22', and 'KDML105' showed similar level of heat sensitivity as 'IR64'. For 'KDML105', an economically important aromatic rice cultivar, limited information exists on its physiological responses to high temperature treatments. Impact of temperature on plants varies depending on the level of temperature and the time of exposure which are divided into short- (up to $1 \mathrm{~h}$ ), moderate short- ( $1 \mathrm{~h}$ up to $24 \mathrm{~h}$ ) and long-term temperature (longer than $24 \mathrm{~h}$ ). There was less knowledge in effect of short-term temperature on physiology in various plants including rice plants. Therefore, this research investigated the oxidative stress, membrane stability and antioxidant enzyme activity (POX, CAT, APX, SOD and GR) in Thai aromatic rice 'KDML105' compared to standard heat tolerance rice 'Dular' (Lang et al., 2015) and standard heat sensitive rice 'IR64' (Coast et al., 2016) exposed to short-term temperature treatments $\left(25,35\right.$ and $45^{\circ} \mathrm{C}$ for $\left.30 \mathrm{~min}\right)$.

\section{MATERIALS AND METHODS}

\section{Plant material and growth condition}

Three rice (Oryza sativa L.) cultivars were evaluated in this study: heat tolerant 'Dular' (Lang et al., 2015), heat sensitive 'IR64' (Coast et al., 2016) and 'KDML105'. The seeds were sterilized with 70\% ethanol for 1 min, washed with distilled water three times, soaked in $10 \%$ sodium hypochlorite for $15 \mathrm{~min}$ and washed with distilled water three times. Sterilized seeds were imbibed in distilled water for $1 \mathrm{~d}$. After that, seeds were germinated on wet seed germination paper until root length was approximately $3 \mathrm{~cm}$. Twenty germinated seeds were transplanted in 36 pots (pot size approximately $12.5 \mathrm{~L}$ ) containing $8 \mathrm{~kg}$ paddy soils per pot. The paddy soil in this experiment had a texture of sandy soil with $\mathrm{pH} 5.18$, organic matter $0.487 \%$, total $\mathrm{N} 0.0235 \%$, available P $5.64 \mathrm{mg} \mathrm{kg}^{-1}$, exchangeable $\mathrm{K} 37.28 \mathrm{mg} \mathrm{kg}^{-1}$ and electrical conductivity (EC) $0.05 \mathrm{dS} \mathrm{m}^{-1}$. The seedlings were grown for $21 \mathrm{~d}$. Then, seedlings were subjected to different temperature regimes in a temperature chamber (VRV Corporation, Bangkok, Thailand). The temperature regimes used for rice seedlings are shown in Figure 1. The temperature in the chamber started at $25^{\circ} \mathrm{C}$ and increased up to 25,35 or $45^{\circ} \mathrm{C}$ for 30 min (Figure 1). Time courses of increasing temperature from $25^{\circ} \mathrm{C}$ reached to 35 or $45^{\circ} \mathrm{C}$ were $50 \mathrm{~min}$ and $1 \mathrm{~h} 36 \mathrm{~min}$, respectively and then decreasing temperature from 35 or $45^{\circ} \mathrm{C}$ reached to $25^{\circ} \mathrm{C}$ were $50 \mathrm{~min}$ and $1 \mathrm{~h} 36 \mathrm{~min}$, respectively. The relative humidity and light intensity in the chamber were controlled at $70 \%$ and $400 \mu \mathrm{mol}$ photons $\mathrm{m}^{-2} \mathrm{~s}^{-1}$, respectively. After target temperature was reached, it was maintained for $30 \mathrm{~min}$ and then cooled down to $25^{\circ} \mathrm{C}$ (Dongsansuk et al., 2017). Immediately after removal of pots from the chamber, fully expanded leaves of the treated plants were collected for the determination of $\mathrm{H}_{2} \mathrm{O}_{2}$, electrolyte leakage (EL) and antioxidant enzymes activity including peroxidase (POX), catalase (CAT), ascorbate peroxidase (APX), superoxide dismutase (SOD) and glutathione reductase (GR).

Figure 1. Model of temperature control in the temperature chamber.

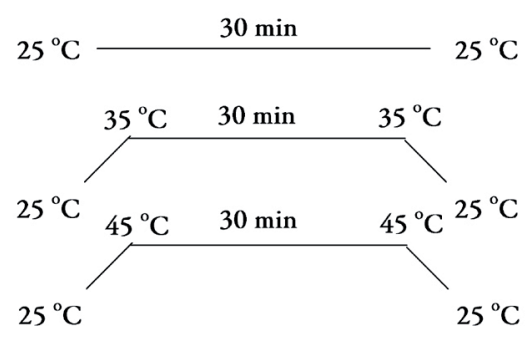




\section{Determination of electrolyte leakage}

Electrolyte leakage (EL) was determined according to Bajji et al. (2002). Fresh leaves $(0.1 \mathrm{~g})$ were placed in a $15 \mathrm{~mL}$ test tube containing $10 \mathrm{~mL}$ deionized water (DI water) and incubated at room temperature for $24 \mathrm{~h}$. The $\mathrm{EC}$ of the suspension $\left(\mathrm{EC}_{1}\right)$ was measured by using EC meter (Tomy Model ES-315, Tomy Seiko, Japan), and the tube was then heated to $100{ }^{\circ} \mathrm{C}$ for 15 min. The samples were then cooled to $25^{\circ} \mathrm{C}$ and the final $\mathrm{EC}\left(\mathrm{EC}_{2}\right)$ was measured. The EL was calculated according to the following equation:

$$
\mathrm{EL}(\%)=\left(\mathrm{EC}_{1} / \mathrm{EC}_{2}\right) \times 100
$$

\section{Determination of protein content and antioxidant enzyme activity}

Protein was extracted by the modified method of Velikova et al. (2000). A sample of $2 \mathrm{~g}$ fresh leaves was ground with liquid nitrogen. After that, $6 \mathrm{~mL} 100 \mathrm{mM}$ potassium phosphate buffer $\mathrm{pH} 7.0$ containing $1 \%$ (w/v) polyvinylpyrrolidone (PVP) was added. The crude extract was centrifuged at $4500 \times \mathrm{g}$ for $1 \mathrm{~h}$ at $4{ }^{\circ} \mathrm{C}$, and supernatant was used as enzyme extracts. Protein content was quantified according to Bradford (1976).

Hydrogen peroxide $\left(\mathrm{H}_{2} \mathrm{O}_{2}\right)$ content was determined using a colorimetric assay based on the reaction producing a yellow complex of ammonium molybdate which absorbs light at $405 \mathrm{~nm}$ according to the method of Góth (1991). Measurement of $\mathrm{H}_{2} \mathrm{O}_{2}$ content was extracted from protein extract, containing $1 \mathrm{~mL}$ crude protein (dilute $10 \mathrm{X}$ ) with $20 \mu \mathrm{L} 0.5 \%$ (w/v) trichloroacetic acid (TCA). The reaction mixture (100 $\mu \mathrm{L}$ protein extract and $100 \mu \mathrm{L} 32.4 \mathrm{mM}$ ammonium molybdate) was prepared in a 96-well microplate and set aside for $10 \mathrm{~min}$, and the absorbance at $405 \mathrm{~nm}$ was measured in an auto microplate reader (UT-2100C, MRC Ltd., Holon, Israel) and expressed as mmol g-1 FW.

Peroxidase (POX) activity was determined according to Chance and Maehly (1955). The assay of POX activity was measured as the rate of increase in the reaction product. The $25 \mu \mathrm{L}$ of $3 \mu \mathrm{g}$ protein extract was added to the reaction mixture $\left(75 \mu \mathrm{L} 100 \mu \mathrm{M}\right.$ potassium phosphate buffer $\mathrm{pH}$ 6.0,50 $\mu \mathrm{L} 120 \mu \mathrm{M}$ guaiacol solution and $\left.50 \mu \mathrm{L} 20 \mu \mathrm{M} \mathrm{H}_{2} \mathrm{O}_{2}\right)$. The absorbance was measured with fluorescence microplate reader (SpectraMax M5, Molecular Devices LLC, Sunnyvale, California, USA) at wavelength $415 \mathrm{~nm}$. The activity was expressed as $\mathrm{mOD} \mathrm{min}^{-1} \mu \mathrm{g}^{-1}$ protein.

Catalase (CAT) activity was determined according to Aebi (1984). Analysis of CAT activity was based on the measurement of remaining $\mathrm{H}_{2} \mathrm{O}_{2}$ content in the reaction mixture, of which absorbance was measured at $240 \mathrm{~nm}$. The $25 \mu \mathrm{L} 10 \mu \mathrm{g}$ protein extract was added to reaction mixture $\left(150 \mu \mathrm{L} 50 \mu \mathrm{M}\right.$ potassium phosphate buffer $\mathrm{pH} 7.0$ and $\left.25 \mu \mathrm{L} 100 \mu \mathrm{M} \mathrm{H}_{2} \mathrm{O}_{2}\right)$. The absorbance was measured with fluorescence microplate reader (SpectraMax M5) at wavelength $240 \mathrm{~nm}$. An enzyme unit was calculated by standard curve of $\mathrm{H}_{2} \mathrm{O}_{2}$ and the activity was expressed as nmol $\min ^{-1} \mu \mathrm{g}^{-1}$ protein.

Ascorbate peroxidase (APX) activity was determined according to Nakano and Asada (1987). The APX activity was measured based on the decrease in absorbance of ascorbic acid at $290 \mathrm{~nm}$. The $25 \mu \mathrm{L} 10 \mu \mathrm{g}$ protein extraction was added to the reaction mixture (100 $\mu \mathrm{L} 100 \mu \mathrm{M}$ potassium phosphate buffer $\mathrm{pH} 7.0,40 \mu \mathrm{L} 5 \mathrm{mM}$ ascorbic acid and $\left.35 \mu \mathrm{L} 20 \mu \mathrm{M} \mathrm{H}_{2} \mathrm{O}_{2}\right)$. The absorbance was measured with fluorescence microplate reader (SpectraMax M5) at wavelength $290 \mathrm{~nm}$. An enzyme unit was calculated by standard curve of ascorbic acid and the activity was expressed as ng ascorbic acid $\min ^{-1} \mu \mathrm{g}^{-1}$ protein.

Superoxide dismutase (SOD) activity was determined according to Beauchamp and Fridovich (1971). Analysis of SOD activity was based on the ability of SOD to inhibit the reduction of nitroblue tetrazolium salt (NBT) by superoxide radicals. The $25 \mu \mathrm{L} 20 \mu \mathrm{g}$ protein extract was added to the reaction mixture (100 $\mu \mathrm{L} 50 \mathrm{mM}$ potassium phosphate buffer pH 7.8, $20 \mu \mathrm{L} 2.5 \mathrm{mM}$ xanthine, $42 \mu \mathrm{L}$ distilled water, $5 \mu \mathrm{L} 20 \mathrm{mM}$ NBT solution and $8 \mu \mathrm{L} 0.05 \mu \mathrm{g}$ xanthine oxidase). The absorbance of reduced product of NBT was measured with fluorescence microplate reader (SpectraMax M5) at wavelength $550 \mathrm{~nm}$. One unit of SOD enzyme activity is defined as the amount of enzyme causing 50\% NBT reaction. The SOD enzyme activity was expressed as unit $\min ^{-1} \mu \mathrm{g}^{-1}$ protein.

Glutathione reductase (GR) activity was determined according to modified method from Carlberg and Mannervik (1985). The unit of GR was calculated from the extinction coefficient of NADPH at $6.2 \mathrm{mM} \mathrm{cm}^{-1}$. The $25 \mu \mathrm{L} 30 \mu \mathrm{g}$ protein extract was added to the reaction mixture $(145 \mu \mathrm{L} 50 \mathrm{mM}$ potassium phosphate buffer $\mathrm{pH}$ 7.4, $10 \mu \mathrm{L} 20 \mathrm{mM}$ EDTA, $10 \mu \mathrm{L} 10 \mathrm{mM}$ NADPH and $10 \mu \mathrm{L} 20 \mathrm{mM}$ GSSG). The absorbance was measured with fluorescence microplate reader (SpectraMax M5) at wavelength $340 \mathrm{~nm}$. The GR activity was determined by the extinction coefficient of NADPH and expressed as $\mu \mathrm{M} \min ^{-1} \mu \mathrm{g}^{-1}$ protein. 


\section{Experimental design and data analysis}

The experimental design was Factorial in completely randomized design (CRD) with four replicates, each of one pot with two factors: (1) three rice cultivars (Dular, IR64 and KDML105) and (2) three temperatures of 25, 35 and $45^{\circ} \mathrm{C}$. Data were analyzed by ANOVA. Significant differences among various treatments were determined by Duncan's multiple range tests (DMRT) using SPSS for Windows version 17.0 (IBM, Armonk, New York, USA).

\section{RESULTS}

\section{Effect of short-term temperature exposure on oxidative stress}

The oxidative stress affected from short-term temperature was indicated by hydrogen peroxide $\left(\mathrm{H}_{2} \mathrm{O}_{2}\right)$ contents (Figure 2). The highest $\mathrm{H}_{2} \mathrm{O}_{2}$ content was observed in rice 'KDML105' (approximately $0.27 \mathrm{mmol} \mathrm{g}{ }^{-1} \mathrm{FW}$ ) after short-term temperature at $35{ }^{\circ} \mathrm{C}$. Seedlings of all three rice cultivars exhibited the highest $\mathrm{H}_{2} \mathrm{O}_{2}$ contents with increasing temperature at $35^{\circ} \mathrm{C}$ for $30 \mathrm{~min}$. This result related to the interaction between the cultivars and temperature $(\mathrm{CV} \times \mathrm{Temp})$ showed significant difference for $\mathrm{H}_{2} \mathrm{O}_{2}$ contents (Table 1). After short-heat exposure at $45^{\circ} \mathrm{C}$, rice 'Dular' and 'KDML105' showed a gradual decreased $\mathrm{H}_{2} \mathrm{O}_{2}$ contents, whereas 'IR64' exhibited nonsignificant slightly decreased $\mathrm{H}_{2} \mathrm{O}_{2}$ contents (Figure 2).

\section{Effect of short-term temperature exposure on membrane stability}

The effect of short-term temperature exposure on membrane stability was measured by electrolyte leakage (EL) (Figure 3); $\mathrm{CV} \times \mathrm{Temp}$ interaction was significant for EL (Table 1). The significant differences were mainly due to low and high temperature stimulating EL of all the rice cultivars (Figure 3, Table 1). According to the higher EL was found in seedlings of all rice cultivars after treated with short-term temperature at 25 and $45^{\circ} \mathrm{C}$. The lowest EL levels were found at $35^{\circ} \mathrm{C}$ in 'IR64', followed by 'KDML105' and 'Dular', respectively (Figure 3).

\section{Effect of short-term temperature exposure on protein content and antioxidant enzyme activity}

The effect of short-term temperature on protein content in three rice seedling cultivars is shown in Figure $4 \mathrm{~A}$. At $25^{\circ} \mathrm{C}$, seedlings of 'IR64' had the highest protein content among the three cultivars. After an exposure to $35^{\circ} \mathrm{C}$, protein content significantly increased in 'Dular' and 'KDML105' (CV $\times$ Temp interaction was significant for protein content; Table 1). In contrast, protein content in 'IR64' significantly decreased. And at this temperature all three cultivars showed comparable amount of proteins in their tissues. When temperature was raised to $45^{\circ} \mathrm{C}$, only 'Dular' showed a significant reduction in protein content. The 'IR64' showed a slight reduction in protein content, while no reduction was observed in 'KDML105'.

Figure 2. Effect of short-term exposure of different temperatures on hydrogen peroxide $\left(\mathrm{H}_{2} \mathrm{O}_{2}\right)$ contents in three rice cultivars.

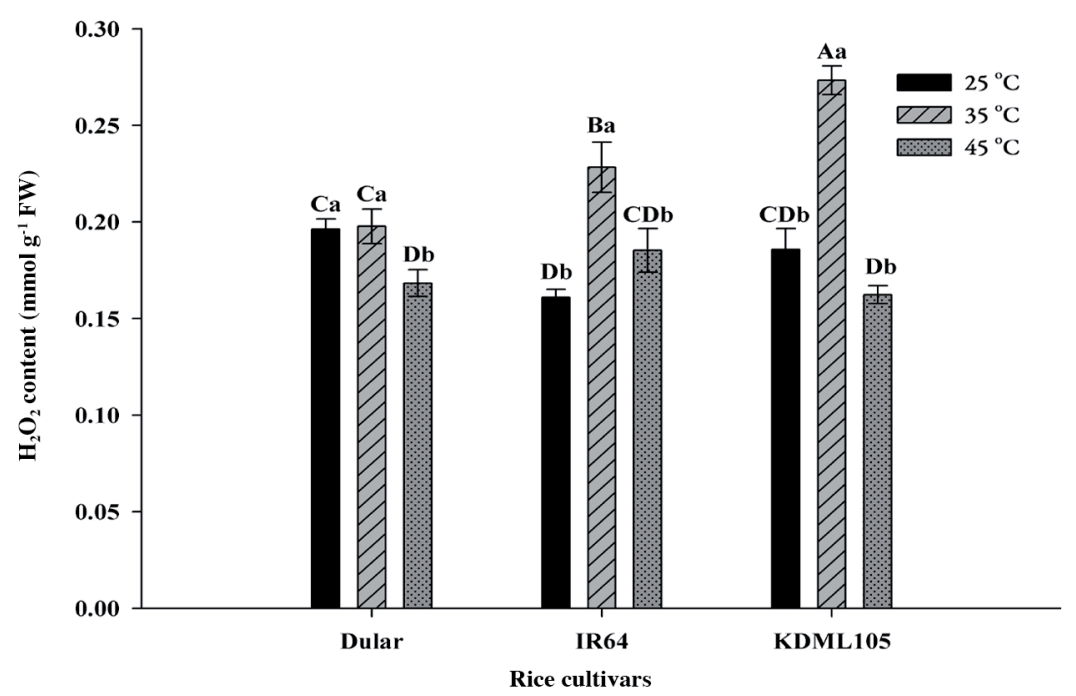

Values were means \pm SE $(n=3-4)$. Different uppercase letters indicated significant differences among different temperatures and cultivars according to Duncan's multiple range tests (DMRT) at $\mathrm{P} \leq 0.05$. Different lowercase letters indicated significant differences among different temperatures in each cultivar by DMRT at $\mathrm{P} \leq 0.05$. 
Table 1. ANOVA of effects of different rice cultivars and different temperatures on hydrogen peroxide $\left(\mathrm{H}_{2} \mathrm{O}_{2}\right)$, electrolyte leakage (EL), protein and antioxidant enzyme activities $(n=3-4)$.

\begin{tabular}{llrrrrrrr}
\hline & \multicolumn{7}{c}{ Mean square } \\
\cline { 2 - 9 } Sources & $\mathrm{H}_{2} \mathrm{O}_{2}$ & \multicolumn{1}{c}{ EL } & Protein & \multicolumn{1}{c}{ POX } & \multicolumn{1}{c}{ CAT } & \multicolumn{1}{c}{ APX } & SOD & GR \\
\hline Cultivars (CV) & $0.001^{*}$ & $223.73^{*}$ & $0.815^{*}$ & $40698.25^{*}$ & $5.511^{*}$ & $5034.62^{*}$ & $0.000^{*}$ & $0.005^{*}$ \\
Temperature (Temp) & $0.010^{*}$ & $3815.16^{*}$ & $0.368^{*}$ & $18555.40^{*}$ & $38.60^{*}$ & $64362.13^{*}$ & $0.000^{*}$ & $0.006^{*}$ \\
$\mathrm{CV} \times$ Temp & $0.002^{*}$ & $221.85^{*}$ & $0.618^{*}$ & $5788.72^{*}$ & $204.97^{*}$ & $19305.44^{*}$ & $0.000^{*}$ & $0.001^{*}$ \\
Error & 0.000 & 42.05 & 0.025 & 25.66 & 0.741 & 60.73 & 0.000 & 0.000 \\
\hline
\end{tabular}

"Indicated significantly different at $\mathrm{P} \leq 0.05$ by ANOVA.

POX: Peroxidase; CAT: catalase; APX: ascorbate peroxidase; SOD: superoxide dismutase; GR: glutathione reductase.

Figure 3. Effect of short-term exposure of different temperatures on electrolyte leakage in three rice cultivars.

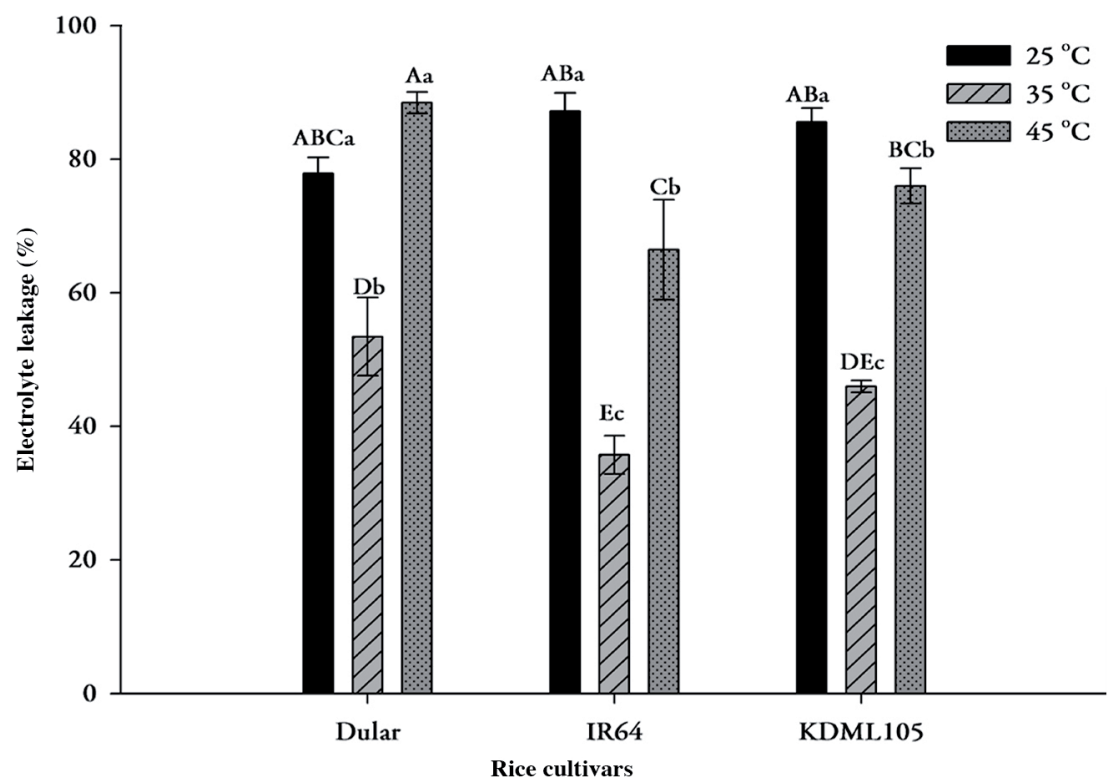

The values were means \pm SE $(n=3-4)$. Different uppercase letters indicated significant differences among different temperatures and cultivars according to Duncan's multiple range tests (DMRT) at $\mathrm{P} \leq 0.05$. Different lowercase letters indicated significant differences among different temperatures in each cultivar by DMRT at $\mathrm{P} \leq 0.05$.

The activities of peroxidase (POX), catalase (CAT), ascorbate peroxidase (APX), superoxide dismutase (SOD) and glutathione reductase (GR) in different rice seedling cultivars are shown in Figures 4B-4F.

The effect of short-term temperature exposure on POX activity is shown in Figure 4B. At $25^{\circ} \mathrm{C}$, the highest POX activity was found in 'IR64' followed by 'KDML105' and 'Dular'. After an exposure to $35^{\circ} \mathrm{C}$, only 'Dular' responded with a significant increase in POX activity. In contrast, the enzyme activity was significantly reduced in 'IR64' and 'KDML105'. A further increase in temperature to $45^{\circ} \mathrm{C}$ resulted in significant reductions in POX activity in all cultivars. This result was related to $\mathrm{CV} \times \mathrm{Temp}$ interaction which showed significant difference (Table 1). At this high temperature 'Dular' showed the most dramatic reduction leading to this cultivar having the lowest POX activity. At all three temperature regimes, 'IR64' demonstrated the highest POX activity. Among all treatment and cultivar combinations, the highest POX activity was found in 'IR64' at $25^{\circ} \mathrm{C}$, followed by 'IR64' at $35^{\circ} \mathrm{C}$ and 'KDML105' at $25^{\circ} \mathrm{C}$. The lowest POX activity was found in 'Dular' at $45^{\circ} \mathrm{C}$.

The effect of short-term temperature exposure on CAT activity is shown in Figure $4 \mathrm{C}$. At $25^{\circ} \mathrm{C}$, 'Dular' presented the highest CAT activity, which was significantly higher than those of 'IR64' and 'KDML105' (CV $\times$ Temp interaction was significant for CAT activity; Table 1). Rice 'Dular' showed decreased trend of CAT activity with increasing temperature from 25 to $45^{\circ} \mathrm{C}$. In contrast, CAT activity of 'IR64' increased with increasing temperatures, producing the highest activity among genotypes at $45^{\circ} \mathrm{C}$. 'KDML105' showed a significant increase in CAT activity at $35{ }^{\circ} \mathrm{C}$ and then the activity 
significantly reduced at $45^{\circ} \mathrm{C}$ to the level slightly higher than that at $25^{\circ} \mathrm{C}$. Among all treatment and cultivar combinations, the highest CAT activity was found in 'IR64' at $45^{\circ} \mathrm{C}$, followed by 'KDML105' at $35^{\circ} \mathrm{C}$ and 'Dular' at $25^{\circ} \mathrm{C}$.

The effect of short-term temperature exposure on APX activity is shown in Figure 4D. At $25^{\circ} \mathrm{C}$, the highest APX activity was found in 'KDML105', which increased when exposed to $35^{\circ} \mathrm{C}$, but decreased at $45^{\circ} \mathrm{C}$ to levels slightly higher than that at $25^{\circ} \mathrm{C}$. Both, 'Dular' and 'IR64', showed slightly APX activity at $25^{\circ} \mathrm{C}$ but significantly increased when exposed to 35 and $45^{\circ} \mathrm{C}(\mathrm{CV} \times$ Temp interaction was significant for APX activity; Table 1). In 'Dular' and 'IR64' the highest activity was found at $45^{\circ} \mathrm{C}$.

Figure 4. Effect of different temperatures on protein contents (A) POX (B), CAT (C), APX (D), SOD (E) and GR (F) activities in three rice cultivars.

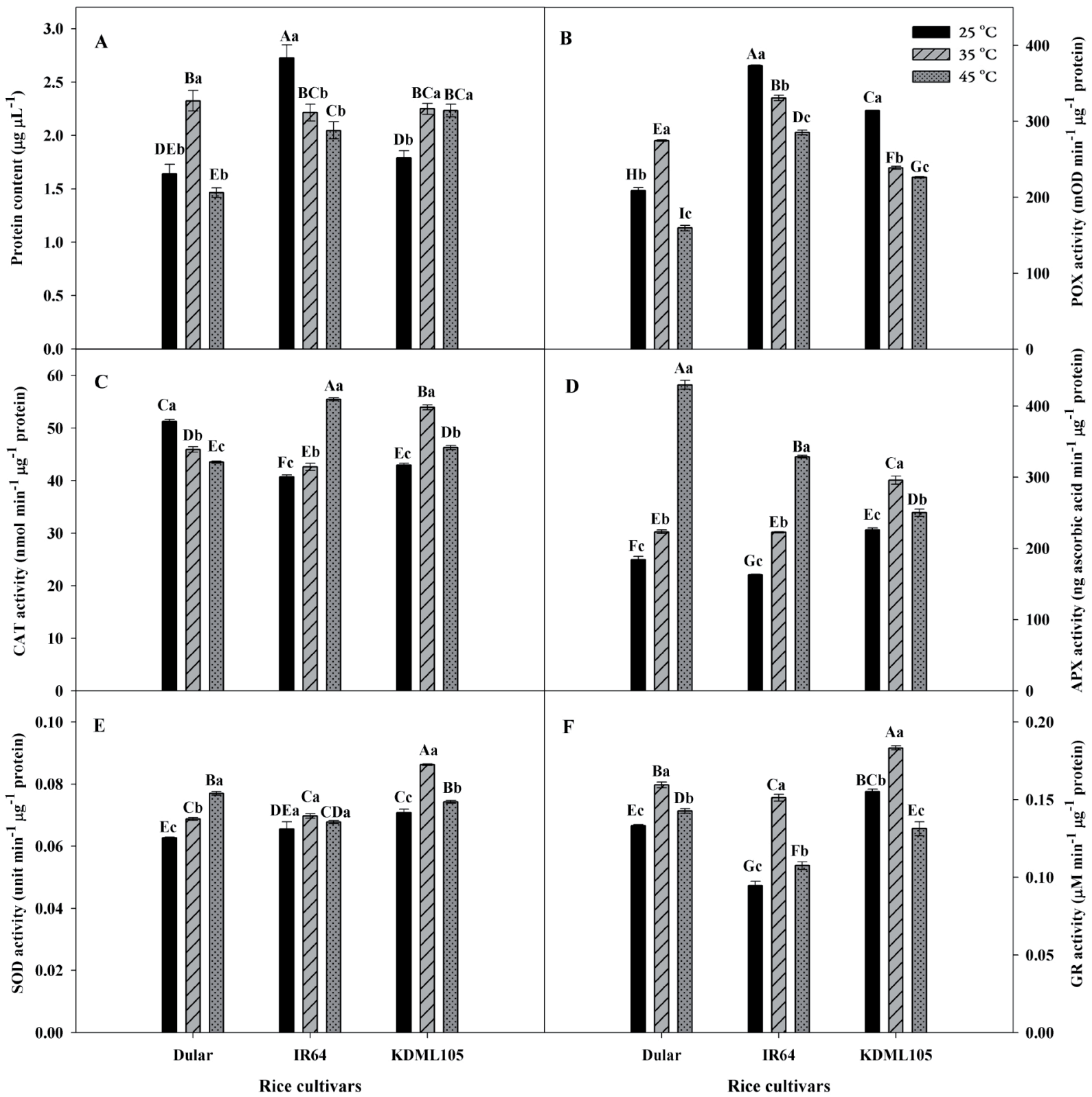

The values were means \pm SE $(n=3-4)$. Different uppercase letters indicated significant differences among different temperatures and cultivars according to Duncan's multiple range tests (DMRT) at $\mathrm{P} \leq 0.05$. Different lowercase letters indicated significant differences among different temperatures in each cultivar by DMRT at $\mathrm{P} \leq 0.05$.

POX: Peroxidase; CAT: catalase; APX: ascorbate peroxidase; SOD: superoxide dismutase; GR: glutathione reductase. 
The effect of short-term temperature exposure on SOD activity is shown in Figure 4E. From Table 1, CV $\times$ Temp interaction was significant for SOD activity. The significant difference was mainly due to different temperatures affecting SOD activity in all the rice cultivars (Figure 4E and Table 1). The three cultivars exhibited different patterns of responses to temperatures. At $25^{\circ} \mathrm{C}$, the highest SOD activity was found in 'KDML105' which was slightly higher than that of 'Dular' and 'IR64'. In response to increasing temperatures, only 'Dular' showed significantly increasing SOD activities from 25 to 35 and $45^{\circ} \mathrm{C}$. 'IR64' showed a slight increase in SOD activity when temperature increased from 25 to $35^{\circ} \mathrm{C}$. The SOD activity of 'KDML105' significantly increased when temperature was raised from 25 to $35^{\circ} \mathrm{C}$, but as the temperature increased to $45^{\circ} \mathrm{C}$, SOD activity reduced to the level slightly higher than the original level at $25^{\circ} \mathrm{C}$. Among all treatment and cultivar combinations, the highest SOD activity was found in 'KDML $105^{\prime}$ ' at $35^{\circ} \mathrm{C}$.

The effect of short-term temperature exposure on GR activity is shown in Figure 4F. At $25{ }^{\circ} \mathrm{C}$, the GR activity was highest in 'KDML105' followed by 'Dular' and 'IR64'. The patterns of responses to various temperatures were similar for all cultivars in which enzyme activity significantly increased at $35^{\circ} \mathrm{C}$ but then decreased when exposed to $45^{\circ} \mathrm{C}$. This result related to $\mathrm{CV} \times$ Temp interaction showed significant difference (Table 1). The GR activities for 'Dular' and 'IR64' at $45^{\circ} \mathrm{C}$ were slightly higher than those at $25^{\circ} \mathrm{C}$. But the GR activity for 'KDML 105 ' at $45^{\circ} \mathrm{C}$ reduced to the level significantly lower than that at $25^{\circ} \mathrm{C}$. Among all treatment and cultivar combinations, the highest GR activity was found in 'KDML105' at $35^{\circ} \mathrm{C}$ followed by 'Dular' at $35^{\circ} \mathrm{C}$, 'KDML105' at $25^{\circ} \mathrm{C}$ and 'IR64' at $35^{\circ} \mathrm{C}$.

\section{Interaction of rice cultivars and temperatures on $\mathrm{H}_{2} \mathrm{O}_{2}$, EL, protein, POX, CAT, APX, SOD and GR}

The interaction of various rice cultivars and temperatures influenced $\mathrm{H}_{2} \mathrm{O}_{2}$ contents, EL, protein content, POX, CAT, APX, SOD and GR (Table 1). We further determined that this interaction of rice cultivars and temperatures significantly $(\mathrm{P} \leq 0.05)$ affected oxidative stress, membrane stability, protein content and antioxidant enzyme activities.

The correlation between $\mathrm{H}_{2} \mathrm{O}_{2}$ contents, EL, protein content, POX, CAT, APX, SOD and GR in three rice cultivars exposed to short-term temperature is shown in Table 2. At $25^{\circ} \mathrm{C}, \mathrm{H}_{2} \mathrm{O}_{2}$ contents showed negative correlations with EL, protein content and POX but it showed positive correlations with CAT, APX and GR. Within the same temperature

Table 2. Correlation coefficient between hydrogen peroxide $\left(\mathrm{H}_{2} \mathrm{O}_{2}\right)$ electrolyte leakage (EL), protein, and antioxidant enzyme activities in rice seedling 'Dular', 'IR64' and 'KDML105' after treated with 25,35 and $45{ }^{\circ} \mathrm{C}$ for $30 \mathrm{~min}(\mathrm{n}=3-4)$.

\begin{tabular}{|c|c|c|c|c|c|c|c|c|c|}
\hline Sources & ${ }^{\circ} \mathrm{C}$ & $\mathrm{H}_{2} \mathrm{O}_{2}$ & EL & Protein & POX & CAT & APX & SOD & GR \\
\hline \multirow[t]{3}{*}{$\mathrm{H}_{2} \mathrm{O}_{2}$} & 25 & 1 & $-0.706^{*}$ & -0.664 & $-0.763^{*}$ & $0.735^{*}$ & 0.426 & 0.060 & 0.616 \\
\hline & 35 & 1 & -0.250 & 0.017 & -0.407 & $0.694 *$ & $0.809^{* *}$ & $0.876^{* *}$ & $0.684 *$ \\
\hline & 45 & 1 & -0.465 & 0.004 & 0.485 & 0.555 & 0.083 & -0.625 & -0.497 \\
\hline \multirow[t]{3}{*}{ EL } & 25 & $-0.706^{*}$ & 1 & 0.564 & $0.756^{*}$ & $-0.736^{*}$ & -0.024 & 0.077 & -0.226 \\
\hline & 35 & -0.250 & 1 & -0.410 & -0.541 & 0.402 & 0.073 & 0.067 & 0.208 \\
\hline & 45 & -0.465 & 1 & $-0.678^{*}$ & $-0.782 *$ & $-0.718 *$ & 0.484 & $0.725^{*}$ & 0.624 \\
\hline \multirow[t]{3}{*}{ Protein } & 25 & -0.664 & 0.564 & 1 & $0.796^{* *}$ & $-0.692 *$ & $-0.660^{*}$ & 0.047 & $-0.854 * *$ \\
\hline & 35 & 0.017 & -0.410 & 1 & -0.112 & -0.115 & -0.063 & -0.130 & 0.029 \\
\hline & 45 & 0.004 & $-0.678 *$ & 1 & $0.701 *$ & 0.441 & $-0.923 * *$ & -0.488 & -0.521 \\
\hline \multirow[t]{3}{*}{ POX } & 25 & $-0.763^{*}$ & $0.756^{*}$ & $0.796^{* *}$ & 1 & $-0.969 * *$ & -0.165 & 0.378 & -0.494 \\
\hline & 35 & -0.407 & -0.541 & -0.112 & 1 & $-0.914 * *$ & $-0.779 * *$ & $-0.748 * *$ & $-0.893 * *$ \\
\hline & 45 & 0.485 & $-0.782 *$ & $0.701 *$ & 1 & $0.935^{* *}$ & $-0.589 *$ & $-0.954 * *$ & $-0.905 * *$ \\
\hline \multirow[t]{3}{*}{ CAT } & 25 & $0.735^{*}$ & $-0.736^{*}$ & $-0.692 *$ & $-0.969 * *$ & 1 & 0.029 & -0.496 & 0.343 \\
\hline & 35 & $0.694 *$ & 0.402 & -0.115 & $-0.914 * *$ & 1 & $0.924 * *$ & $0.932 * *$ & $0.951 * *$ \\
\hline & 45 & 0.555 & $-0.718 *$ & 0.441 & $0.935^{* *}$ & 1 & -0.280 & $-0.970 * *$ & $-0.919 * *$ \\
\hline \multirow[t]{3}{*}{ APX } & 25 & 0.426 & -0.024 & $-0.660 *$ & -0.165 & 0.029 & 1 & $0.587 *$ & $0.921 * *$ \\
\hline & 35 & $0.809 * *$ & 0.073 & -0.063 & $-0.779 * *$ & $0.924 * *$ & 1 & $0.975^{* *}$ & $0.939 * *$ \\
\hline & 45 & 0.083 & 0.484 & $-0.923 * *$ & $-0.589 *$ & -0.280 & 1 & 0.357 & 0.373 \\
\hline \multirow[t]{3}{*}{ SOD } & 25 & 0.060 & 0.077 & 0.047 & 0.378 & -0.496 & $0.587 *$ & 1 & 0.352 \\
\hline & 35 & $0.876^{* *}$ & 0.067 & -0.130 & $-0.748 * *$ & $0.932 * *$ & $0.975^{* *}$ & 1 & $0.917 * *$ \\
\hline & 45 & -0.625 & $0.725 *$ & -0.488 & $-0.954 * *$ & $-0.970 * *$ & 0.357 & 1 & $0.902 * *$ \\
\hline \multirow[t]{3}{*}{ GR } & 25 & 0.616 & -0.226 & $-0.854 * *$ & -0.494 & 0.343 & $0.921^{* *}$ & 0.352 & 1 \\
\hline & 35 & $0.684 *$ & 0.208 & 0.029 & $-0.893 * *$ & $0.951 * *$ & $0.939 * *$ & $0.917 * *$ & 1 \\
\hline & 45 & -0.497 & 0.624 & -0.521 & $-0.905^{* *}$ & $-0.919 * *$ & 0.373 & $0.902 * *$ & 1 \\
\hline
\end{tabular}

*,**Significantly different by ANOVA at $\mathrm{P} \leq 0.05$ and 0.01 , respectively. POX: Peroxidase; CAT: catalase; APX: ascorbate peroxidase; SOD: superoxide dismutase; GR: glutathione reductase. 
condition, a positive correlation existed between protein content and POX (Table 2). At $35{ }^{\circ} \mathrm{C}$, we found positive correlations between $\mathrm{H}_{2} \mathrm{O}_{2}$ content and CAT, APX, SOD and GR. While, POX correlated negatively with CAT, APX, SOD and GR. At $45^{\circ} \mathrm{C}$, we noted a negative correlation between $\mathrm{H}_{2} \mathrm{O}_{2}$ content and $\mathrm{EL}$ and between protein contents and EL, APX, SOD and GR.

\section{DISCUSSION}

We investigated, herein, the physiological responses of three different rice cultivars at seedling stage to various temperatures. Exposure to various temperatures (at 25,35 and $45^{\circ} \mathrm{C}$ ) for 30 min induced marked changes in physiological and biochemical processes resulting in different performances of the three rice cultivars.

Such short-term temperature at $25^{\circ} \mathrm{C}$ stimulated the highest protein accumulation and the lowest $\mathrm{H}_{2} \mathrm{O}_{2}$ production in rice seedling 'IR64'. Because this temperature condition may stimulate an accumulation of $\mathrm{H}_{2} \mathrm{O}_{2}$-scavenging proteins such as POX (according to positive correlation between protein and POX +0.796 ; Table 2, Figures 4A and 4B) resulting in $\mathrm{H}_{2} \mathrm{O}_{2}$ reduction. $\mathrm{POX}$ is an antioxidant enzyme involving the protection of plant cells. It removes ROS occurring in the cell wall (Jajic et al., 2015) by catalyzing the oxidation of $\mathrm{H}_{2} \mathrm{O}_{2}$. In plant tissues, POX can oxidize phenolic compounds. As a result, heat-sensitive rice seedling 'IR64' (Coast et al., 2016) exposed to $25{ }^{\circ} \mathrm{C}$ for 30 min showed higher POX production, capable of eliminating $\mathrm{H}_{2} \mathrm{O}_{2}$ more effectively than the heat-tolerant 'Dular' (Lang et al., 2015) and tropical rice 'KDML105'. Although, membrane of 'IR64' was highly damaged under this temperature condition (Figure 2), this suggested that the membrane of 'IR64' may recover quickly due to its physiological performance such as photosynthetic efficiency, Hill reaction and photosynthetic pigment contents which were still high under this temperature condition (data not show). Mackill and Khush (2018) produced a breeding program for 'IR64' in International Rice Research Institute (IRRI) in a quest for a high yield and disease and insect resistance cultivar. Unfortunately, 'IR64' is susceptible to low P, Fe toxicity, drought stress and heat.

Under the short-term temperature at $35^{\circ} \mathrm{C}$, the rice seedlings 'Dular', 'IR64' and 'KDML105' showed the highest $\mathrm{H}_{2} \mathrm{O}_{2}$ content but produced the lowest EL. Because plant cells were metabolically active under this temperature condition. Therefore, we suggested that the temperature at $35^{\circ} \mathrm{C}$ was the optimum for each of the three rice cultivars used in this study according to Hasanuzzaman et al. (2013a) and Pansarakham et al. (2018). As a result, it could modulate physiological mechanism including generation of ROS such as $\mathrm{H}_{2} \mathrm{O}_{2}$. According to our result, growing evidence in recent years suggested that ROS production is required for a wide range of plant responses to developmental and environmental cues, leading to growth and acclimation (Foyer and Noctor, 2016). Moreover, $\mathrm{H}_{2} \mathrm{O}_{2}$ is required directly in oxidative cross-linking reactions leading to cell wall strengthening (Smirnoff and Arnaud, 2019). In general, low ROS levels are necessary for the progression of basic biological process including cellular proliferation and differentiation (Huang et al., 2019). Compared with other ROS such as $\mathrm{O}_{2}{ }^{-}$and $\mathrm{OH}^{-}, \mathrm{H}_{2} \mathrm{O}_{2}$ is relatively long-lived, accumulates transiently and functions as signaling molecules in signal transduction pathways influencing gene expression in normal plant development including stomatal functions, root hair and pollen tube growth (Smirnoff and Arnaud, 2019), and in programmed cell death in response to pathogen infections and under temperature stress (Awasthi et al., 2015).

In addition to higher $\mathrm{H}_{2} \mathrm{O}_{2}$ production under short-term temperature at $35^{\circ} \mathrm{C}$, higher protein content was also found at this temperature which may play the important roles in all plant cell processes. In rice seedlings 'Dular' and 'KDML105', especially 'KDML105', higher activity of SOD was induced (Figure 2) hence higher rate of dismutation of $\mathrm{O}_{2}{ }^{-}$to $\mathrm{H}_{2} \mathrm{O}_{2}$ resulting in higher $\mathrm{H}_{2} \mathrm{O}_{2}$ production (Figure 4E). This accorded with positive correlation between $\mathrm{SOD}$ and $\mathrm{H}_{2} \mathrm{O}_{2}(0.876$, Table 2). SOD is a metalloenzyme that plays a central role in the defense of oxidative stress. It scavenges free radicals by dismutation of $\mathrm{O}_{2}{ }^{*-}$ to $\mathrm{O}_{2}$ and $\mathrm{H}_{2} \mathrm{O}_{2}$ (Sharma et al., 2012), thereby decreasing the risk of hydroxyl radical formation in plants. SOD occurs in chloroplast, mitochondria, cytosol, peroxisome and apoplast (Jajic et al., 2015). Within the same temperature condition, CAT activity in 'IR64' and 'KDML105' as well as APX and GR in 'Dular', 'IR64' and 'KDML105' were stimulated by higher $\mathrm{H}_{2} \mathrm{O}_{2}$ production, indicated by a positive correlation between $\mathrm{H}_{2} \mathrm{O}_{2}$ and CAT $(+0.694)$, APX (+0.809) and GR (+0.684) (Table 2). Because $\mathrm{H}_{2} \mathrm{O}_{2}$ also plays a role as signaling molecule to increase antioxidant enzymes. Antioxidant enzymes, such as POX, CAT, APX and GR, and non-enzymatic antioxidants such as ascorbate (AsA), glutathione (GSH) and carotenoid (Hasanuzzaman et al., 2013b), are involved in the protection of plant cells by the elimination of the toxic oxygen intermediates such as $\mathrm{O}_{2}{ }^{-}$and $\mathrm{H}_{2} \mathrm{O}_{2} ;$ CAT, which predominantly occurs in 
peroxisome (Jajic et al., 2015), participates in $\mathrm{H}_{2} \mathrm{O}_{2}$ elimination by directly breaking down the $\mathrm{H}_{2} \mathrm{O}_{2}$ structure to produce water and oxygen molecules.

Environmental stress can cause either increase or decrease CAT activity depending on severity, duration and type of stresses (Sharma et al., 2012). As for APX, it plays a key role in scavenging ROS, protecting plant cells and eliminating $\mathrm{H}_{2} \mathrm{O}_{2}$ in water-water cycle and ascorbate-glutathione cycle. The APX activity occurs in chloroplast, mitochondria and cytosol. With regard to GR, an oxidoreductase enzyme, which eliminates $\mathrm{H}_{2} \mathrm{O}_{2}$ by Halliwell-Asada enzyme pathway, and also plays an important role maintaining the ratio between antioxidant and pro-oxidant in cells. It can be found in chloroplast, mitochondria, cytosol and peroxisomes (Yousuf et al., 2012). Among the roles of antioxidant enzymes (POX, CAT, APX, SOD and GR), it is the elimination of $\mathrm{O}_{2}^{-}$( $\mathrm{Zhu}$ et al., 2020) and $\mathrm{H}_{2} \mathrm{O}_{2}$ resulting in plant cell membrane and organelle membrane unaffected by ROS toxicity, evidenced by lower EL levels at this temperature condition in all rice seedlings (Figure 3).

Notably, membranes of rice seedlings 'Dular', 'IR64' and 'KDML105' after short-term temperature at $45^{\circ} \mathrm{C}$ (shortterm heat stress) were damaged as indicated by higher EL (Figure 3). The membrane is the first part of the cell that recognizes stress from the environment and acts as a signal transmission in plants (Krishnan et al., 2011). Increased heat caused acceleration in the movement of lipids leading an increase in membrane fluidity, denaturation of protein components of the membrane, and finally ion leakage, membrane rupture and inhibition of physiological processes. The EL values, which indicate the degree of membrane damage, was estimated by the electrical conductivity of cell liquid leak from leaf tissues. Consequently, the higher EL value resulting from short-term temperature at $45^{\circ} \mathrm{C}$ resulted in reduced membrane stability. Plant cells were inactive and led to low $\mathrm{H}_{2} \mathrm{O}_{2}$ production accorded to negative correlation between $\mathrm{H}_{2} \mathrm{O}_{2}$ and EL after treated with short-term temperature at $45^{\circ} \mathrm{C}(-0.465$, Table 2). Our results were similar to those of Kaushal et al. (2011), who reported that the highest EL in chickpea was found at $45 / 40{ }^{\circ} \mathrm{C}$ (day/night), as well as those of Timabud (2015) who found the higher EL in rice seedlings 'IR64' (heat susceptible) than those 'N22' (heat tolerant) and 'KDML105'. Borriboon et al. (2018) reported that EL was increased with increasing temperature at $40^{\circ} \mathrm{C}$ for 1 and $2 \mathrm{wk}$ in rice abnormal seedlings ('Dular', 'KDML105' and 'Riceberry'). In their research using rice 'Dular', Pansarakham et al. (2018) showed that leaves at dough grain stage exhibited no changes in EL after short-heat stress at $42{ }^{\circ} \mathrm{C}$ for $30 \mathrm{~min}$. This indicated that leaves of this cultivar had higher level of membrane tolerance at dough grain stage (Pansarakham et al., 2018) than seedling stage (this study). However, leaves of rice 'IR64' and 'KDML105' exhibited membrane damage at both dough grain stage (Pansarakham et al., 2018) and seedling stage (current study).

Moreover, under short-term $45^{\circ} \mathrm{C}$, protein content in 'Dular' and 'IR64' was reduced. Therefore, short or mediumshort exposure to temperature higher than $40{ }^{\circ} \mathrm{C}$ had direct effects on plant injury and protein metabolism by interrupting protein synthesis and increasing protein denaturation and aggregation (Waraich et al., 2012). Consequently, the cause of protein reduction after short-term heat stress (at $45^{\circ} \mathrm{C}$ in this study) may be related to the decrease in the strength of $\mathrm{H}$-bonds and electrostatic interactions between polar groups of proteins within aqueous phase of the membrane resulted in protein disassociation, and then protein molecules became denatured, aggregated and unfunctional. This was according to negative correlation between protein and EL (-0.678, Table2). Moreover, at this temperature condition (short-term heat stress), POX and GR in 'Dular', 'IR64' and 'KDML105', CAT in 'Dular' and 'KDML105' and APX and SOD in 'KDML105' were found significantly decreased activity. Short-term heat stress (at $45^{\circ} \mathrm{C}$ for $30 \mathrm{~min}$ ) may affect these enzymes by protein degradation leading to loss of functions. Heat stress also causes structural proteins and enzymes to become unfolding or misfolding (Usman et al., 2014). These breakdown and aggregation of cellular proteins or enzymes led to loss of protein structure and activity.

\section{CONCLUSIONS}

Among the three temperature treatments, 25,35 and $45^{\circ} \mathrm{C}$, the greatest membrane stability was observed at $35^{\circ} \mathrm{C}$ although the highest $\mathrm{H}_{2} \mathrm{O}_{2}$ content also occurred at this temperature. The higher membrane stability and the highest protein content indicated that rice seedlings were most metabolically active at this temperature, and the $\mathrm{H}_{2} \mathrm{O}_{2}$ level was regulated at the levels high enough to act as signaling molecules for normal growth and developmental processes including the activation of antioxidant enzyme activities. At $35^{\circ} \mathrm{C}$, antioxidant enzyme activity such as superoxide dismutase (in 'Dular' and 'KDML105') and catalase, ascorbate peroxidase and glutathione reductase (in 'Dular', 'IR64' and 'KDML105') were 
stimulated. However, heat stress following a short exposure at $45^{\circ} \mathrm{C}$ resulted in severe membrane damage as indicated by increased electrolyte leakage. At this temperature, the activity of some antioxidant enzymes was reduced compared to the $35^{\circ} \mathrm{C}$ treatment while that of others were enhanced, and different cultivars employed different enzymes to varying extent. In addition, it was found that 'Dular' with short-term temperature at $45^{\circ} \mathrm{C}$ exhibited membrane damage at seedling stage while no membrane damage was observed at dough grain stage. Thus, 'Dular' was heat sensitive at seedling stage while it was heat tolerant at dough grain stage. Short temperature treatment at $25^{\circ} \mathrm{C}$ which was $10^{\circ} \mathrm{C}$ lower than the optimum growth temperature also caused membrane damage leading to more electrolyte leakage than treatment at $35^{\circ} \mathrm{C}$. However, at $25^{\circ} \mathrm{C}$, 'IR64' demonstrated remarkably fast recovery from membrane injury.

\section{ACKNOWLEDGEMENTS}

This research was funded by Research Fund for DPST Graduate with First Placement 2015 and Salt-Tolerant Rice Research Group, Khon Kaen University (KKU). The scientific instruments were supported by the Department of Biology, Department of Biochemistry, Faculty of Science and Department of Agronomy, Faculty of Agriculture, KKU. In addition, the authors wish to thank Assoc. Prof. Dr. Paweena Pongdontri and Dr. Tarinee Timabud for suggesting antioxidant enzyme investigation in this research.

\section{REFERENCES}

Aebi, H. 1984. Catalase in vitro. Methods in Enzymology 105:121-126. doi:10.1016/S0076-6879(84)05016-3.

Ali, K.,Azhar,A., and Galani, S. 2013. Response of rice (Oryza sativa L.) under elevated temperature at early growth stage physiological markers. Russian Journal of Agricultural and Socio-Economic Sciences 8(20):11-19. doi:10.18551/rjoas.2013-08.02.

Asthir, B. 2015. Mechanisms of heat tolerance in crop plants. Biologia Plantarum 59(4):620-628. doi:10.1080/17429145.2015.1067726.

Awasthi, R., Bhandari, K., and Nayyar, H. 2015. Temperature stress and redox homeostasis in agricultural crops. Frontiers in Environmental Science 3:1-24. doi:10.3389/fenvs.2015.00011.

Bajji, M., Lutts, S., and Kinet, J.M. 2002. The use of the electrolyte leakage method for assessing cell membrane stability as a water stress tolerance test in durum wheat. Plant Growth Regulation 36:61-70. doi:10.1023/A:1014732714549.

Beauchamp, C., and Fridovich, I. 1971. Superoxide dismutase: improved assays and an assay applicable to acrylamide gels. Analytical Biochemistry 44(1):276-287. doi:10.1016/0003-2697(71)90370-8.

Bita, C.E., and Gerats, T. 2013. Plant tolerance to high temperature in a changing environment: Scientific fundamentals and production of heat stress-tolerant crops. Frontiers in Plant Science 4:273. doi:10.3389/fpls.2013.00273.

Borriboon, W., Lontom, W., Pongdontri, P., Theerakulpisut, P., and Dongsansuk, A. 2018. Effects of short- and long-term temperature on seed germination, oxidative stress and membrane stability of three rice cultivars (Dular, KDML105 and Riceberry). Pertanika Journal of Tropical Agricultural Science 41(1):151-162.

Bradford, M.M. 1976. A rapid and sensitive method for the quantitation of microgram quantities of protein utilizing the principle of protein-dye binding. Analytical Biochemistry 72(1-2):248-254. doi:10.1016/0003-2697(76)90527-3.

Carlberg, I., and Mannervik, B. 1985. Glutathione reductase. Methods in Enzymology 113:484-490. doi:10.1016/S0076-6879(85)13062-4.

Chance, B., and Maehly, A.C. 1955. Assay of catalase and peroxidases. Methods in Enzymology 2:764-775. doi:10.1016/S0076-6879(55)02300-8.

Coast, O., Murdoch, A.J., Ellis, R.H., Hay, F.R., and Jagadish, K.S.V. 2016. Resilience of rice (Oryza spp.) pollen germination and tube growth to temperature stress. Plant, Cell and Environment 39(1):26-37. doi:10.1111/pce.12475.

Dongsansuk, A., Theerakulpisut, P., and Pongdontri, P. 2017. Short-term heat exposure effect on PSII efficiency and growth of rice (Oryza sativa L.) Pertanika Journal of Tropical Agricultural Science 40(4):621-628.

Foyer, C.H., and Noctor, G. 2016. Stress-triggered redox signalling: what's in pROSpect? Plant, Cell and Environment 39(5):951-964. doi:10.1111/pce.12621.

Góth, L. 1991. A simple method for determination of serum catalase activity and revision of reference range. Clinica Chimica Acta 196(2-3):143-151. doi:10.1016/0006-8981(91)90067-M.

Hasanuzzaman, M., Nahar, K., Alam, Md-M., Roychowdhury, R., and Fujita, M. 2013a. Physiological, biochemical, and molecular mechanisms of heat stress tolerance in plants. International Journal of Molecular Science 14(5):9643-9684. doi:10.3390/ijms14059643.

Hasanuzzaman, M., Nahar, K., and Fujita, M. 2013b. Extreme temperature responses, oxidative stress and antioxidant defense in plants. p. 169-205. In Vahdati, K. and Leslie, C. (eds.) Abiotic stress-plant responses and applications in agriculture. InTech Open, Japan. 
Hemantaranjan,A., Nishant Bhanu,A., Singh, M.N., Yadav, D.K., and Patel,P.K. 2014. Heat stress responses and thermotolerance. Advances in Plants \& Agriculture Research 1(3):62-70. doi:10.15406/apar.2014.01.00012.

Huang, H., Ullah, F., Zhou, D.X., Yi, M., and Zhao, Y. 2019. Mechanisms of ROS regulation of plant development and stress responses. Frontiers in Plant Science 10:800. doi:10.3389/fpls.2019.00800.

Jajic, I., Sarna, T., and Strzalka, K. 2015. Senescence, stress, and reactive oxygen species. Plants 4(3):393-411. doi:10.3390/plants4030393.

Kaushal, N., Gupta, K., Bhandhari, K., Kumar, S., Thakur, P., and Nayyar, H. 2011. Proline induces heat tolerance in chickpea (Cicer arietinum L.) plants by protecting vital enzymes of carbon and antioxidative metabolism. Physiology and Molecular Biology of Plants 17(3):203-213. doi:10.1007/s12298-011-0078-2.

Krishnan, P., Ramakrishnan, B., Raja Reddy, K., and Reddy, V.R. 2011. High-temperature effects on rice growth, yield, and grain quality. p. 87-206. In Sparks, D.L. (ed.) Advances in Agronomy vol. 111. Academic Press, Burlington, USA.

Lang, N.T., Ha, P.T.T., Tru, PC., Toam, T.B., Buu, B.C., and Cho, Y.C. 2015. Breeding for heat tolerance rice based on maker assisted backcrossing in Vietnam. Plant Breeding and Biotechnology 3(3):274-281. doi:10.9787/PBB.2015.3.3.274.

Mackill, D.J., and Khush, G.S. 2018. IR64: a high-quality and high-yielding mega variety. Rice 11:18. doi:10.1186/s12284-018-0208-3.

Nakano, Y., and Asada, K. 1987. Purification of ascorbate peroxidase in spinach chloroplasts; its inactivation in ascorbate depleted medium and reactivation by monodehydroascorbate radical. Plant and Cell Physiology 28(1):131-140. doi:10.1093/oxfordjournals.pcp.a077268.

Pansarakham,P.,Pongdontri,P., Theerakulpisut,P., and Dongsansuk, A. 2018. Effect of short-term heat exposure on physiological traits of rice indica at grain-filling stage. Acta Physiologiae Plantarum 40(9):173. doi:10.1007/s11738-018-2743-3.

Sharma, P., Jha, A.B., Dubey, R.S., and Pessarakli, M. 2012. Reactive oxygen species, oxidative damage, and antioxidative defense mechanism in plants under stressful conditions. Journal of Botany 2012:217037. doi:10.1155/2012/217037.

Smirnoff, N., and Arnaud, D. 2019. Hydrogen peroxide metabolism and functions in plants. New Phytologist 221(3):1197-1214. doi:10.1111/nph.15488.

Sukkeo, S., Rerkasem, B., and Jamjod, S. 2017. Heat tolerance in Thai rice varieties. ScienceAsia 43(2):61-69. doi:10.2306/scienceasia1513-1874.2017.43.061.

Timabud, T. 2015. Effect of heat on oxidative stress and aroma level of Thai aromatic rice. PhD Dissertation, Khon Kaen University, Department of Biochemistry, Khon Kaen, Thailand.

Timabud, T., and Pongdontri, P. 2015. A biochemical approach to evaluate heat tolerant rice. p. 41-47. In The 34 ${ }^{\text {th }}$ National Graduate Research Conference, Faculty of Medicine, Khon Kaen University, Khon Kaen. 27 March. Khon Kaen University, Khon Kaen, Thailand.

Usman, M.G., Rafil, M.Y., Malek, A., and Latif, M.A. 2014. Heat shock proteins: Functions and response against heat stress in plants. International Journal of Scientific \& Technology Research 3(11):204-218.

Velikova, V., Yodanov, I., and Edreva, A. 2000. Oxidative stress and some antioxidant system in acid rain-treated bean plants: protective role of exogenous polyamines. Plant Science 151(1):59-66. doi:10.1016/S0168-9452(99)00197-1.

Waraich, E.A., Ahmad, R., Halim, A., and Aziz, T. 2012. Alleviation of temperature stress by nutrient management in crop plants: a review. Journal of Soil Science and Plant Nutrition 12(2):221-244. doi:10.4067/S0718-95162012000200003.

Yousuf, P.Y., Hakeem, K.U.R., Chandna, R., and Ahmad, P. 2012. Role of glutathione reductase in plant abiotic stress. p. 149158. In Ahmad, P., and Prasad, M.N.V. (eds.) Abiotic stress responses in plants. Springer, New York, USA.

Zhu, G., Wang, Y., Shi, X., Lu, H., Ren, Z., Shi, Y., et al. 2020. Optimum nitrogen management enhances growth, antioxidant ability and yield performance of rice in saline soil of coastal area of China. Chilean Journal of Agricultural Research 80:629-639. doi:10.4067/S0718-58392020000400629. 